\title{
Considerations on Two Cruces Philologorum (Ael. NA 15, 15)
}

\section{Elwira Kaczyńska}

University of Lodz, Faculty of Philology, Chair of Classical Philology,

Dep. of Latin Studies and Linguistics,

ul. Pomorska 171/173, 90-236 Łódź, Poland; elwira.kaczynska@uni.lodz.pl.

For citation: Kaczyńska E. Considerations on Two Cruces Philologorum (Ael. NA 15, 25). Philologia Classica 2021, 16 (1), 32-39. https://doi.org/10.21638/spbu20.2021.103

The present article aims to elucidate an interesting narrative that forms a portion of Aelian's

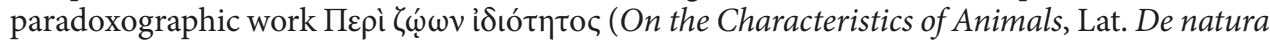
animalium). The passage under discussion describes some horned animals of oriental origin that were involved in the annual fighting contests during a one-day competition held on the initiative of a "great king of India" - probably Chandragupta $\left(4^{\text {th }}-3^{\text {rd }}\right.$ c. BC), the founder of the Maurya dynasty. Aelian's chapter $(N A 15,15)$ was perhaps taken from Megasthenes's

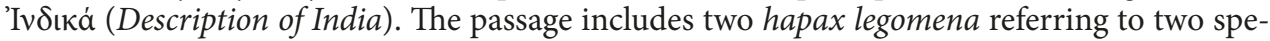
cies of animals: $\dagger \mu \varepsilon \dot{\varepsilon} \sigma o \iota \dagger$ and $\dagger u ̈ a ı v a \dagger \dagger$. The first of these should be identified with the Ladakh urial (Ovis orientalis vignei Blyth); cf. Prasun mașé 'ram, urial' (< Vedic mēșá- m. 'ram'). Aelian's exact description of the horned animals called †úaıvaı clearly demonstrates that the alleged "striped hyena" (Gk. v̌aıva) must represent the chinkara, i. e., the Indian gazelle (Gazella bennettii Sykes). The Indo-Aryan term for 'chinkara' (Ved. hariná- m 'Indian gazelle', hariṇì- $f$. 'female gazelle'; cf. Pa. and Pk. harina- m., harin̄i-f.) suggests that the corrupted form in Ae-

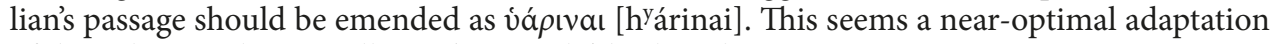
of the Pali or Prakrit appellative hárinā pl. 'chinkaras'.

Keywords: animal terminology, borrowings, etymology, Greek scientific literature, Greek vocabulary, hapax legomena, language contact, Middle Indo-Aryan languages.

\section{Introduction}

Aelian included highly valuable information on the fauna of the Indian subcontinent

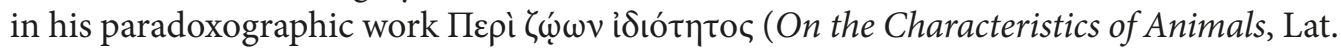
De natura animalium). There is a consensus that he never visited India and learned all the specifics about the local animals from ethnographic-geographical works of Ctesias of Cnidos $\left(5^{\text {th }}-4^{\text {th }} \mathrm{c} . \mathrm{BC}\right)$, the court doctor of Artaxerxes II Memnon (who ruled between 404 and 358 BC), Amyntas ( $4^{\text {th }} \mathrm{c}$.), the historian of Alexander the Great, and Megasthenes $\left(4^{\text {th }}-3^{\text {rd }}\right.$ c. BC), king Seleucus I Nicator's emissary to India. ${ }^{1}$

In one of his accounts (NA 15, 15), Aelian writes that an unnamed Indian king would hold annual fighting contests involving various "horned" animals. ${ }^{2}$ Aelian's account is in-

* The present article is part of the research project entitled Greek-Oriental contacts in a comparative perspective, financed by the scholarly development fund of the Faculty of Philology, University of Lodz. I would like to thank Dr. Maciej Grabski (University of Lodz) for his constant assistance in translating my paper, my husband Prof. Krzysztof Tomasz Witczak (University of Lodz) for his help and encouragement, as well as Prof. Michael L. Weiss (Cornell University) and Prof. Paul Sheldon Cohen (emeritus) for useful comments and improving my English. Of course, all shortcomings are my own.

1 See Maspero 1998, I 19-20.

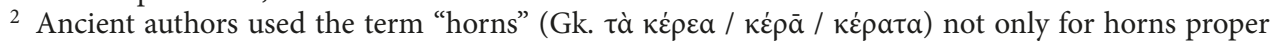
(characteristic of the Bovidae), but also for tusks (in the case of elephants), antlers (in the case of the Cervi-

(C) St. Petersburg State University, 2021 
teresting for two reasons. First, his description includes names of two horned animals

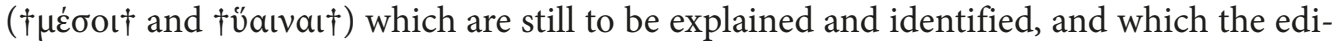
tors consider corrupt and usually mark with a crux philologorum. ${ }^{3}$ Second, to the best of my knowledge, these zoonyms (which I believe to be of Indic origin) have not been the subject of previous investigation. ${ }^{4}$ The aim of this article is to identify the species of the Indian "horned" animals mentioned by Aelian $(N A 15,15)$ and to explicate linguistic discrepancies in their putative names.

\section{Aelian's account of some horned animals of India}

The chapter under analysis (NA 15,15), which begins with the phrase "the great king of the Indian people", is probably based on an account by Megasthenes, the author of the

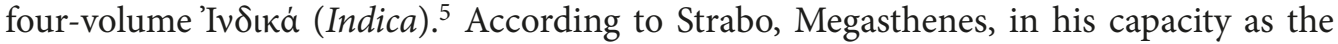
ambassador of the Syrian ruler Seleucus I, was staying at the royal court of Chandragupta, the king of Magadha between 321 and 297 BC and the founder of the Maurya dynasty: ${ }^{6}$

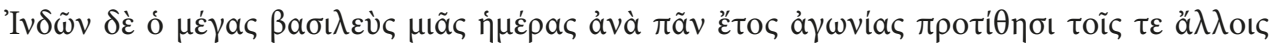

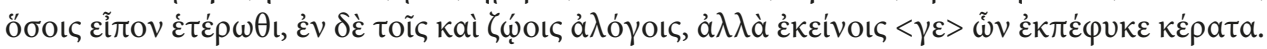

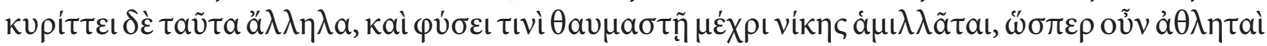

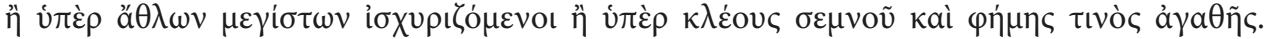

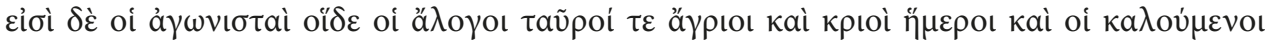

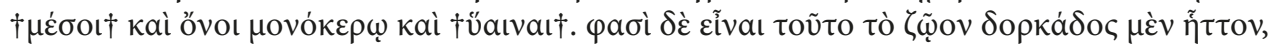

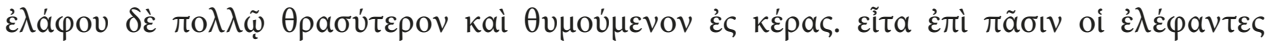

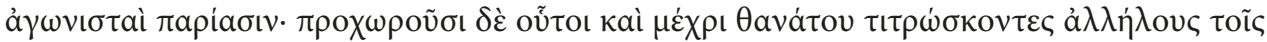

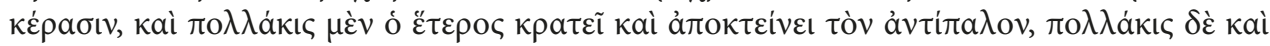

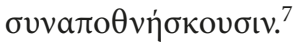

In India the Great King [probably, Chandragupta Maurya] on one day in every year arranges contests not only for various creatures, as I have said elsewhere, but among them between dumb animals also, or at any rate for those which are born with horns. And these butt each other and struggle with an instinct truly astonishing until one is victorious, as in fact athletes do, using all their strength to win the highest prizes or to achieve glorious renown and a noble fame. But these dumb combatants are wild bulls, tame rams, and what are called mesoi [i. e., urials] and one-horned asses [i. e., Indian one-horned rhinoceroses] and hyainai [i. e., Indian gazelles]. They say that this animal is smaller than a gazelle but far more spirited than a stag and that it vents its fury with its horns. And last of all there come forward elephants to the fight: they advance and wound one another to the death with their tusks, and frequently one comes off victor and kills its adversary; frequently also both die together (Transl. Scholfield ${ }^{8}$ ).

dae), and nasal horns (in the case of rhinoceroses).

3 Scholfield 1959, III 236; Maspero 1998, II 872.

4 Brust 2005, passim; Kitchell 2014, 93.

5 Stein 1931, 230-326.

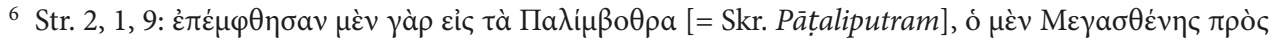

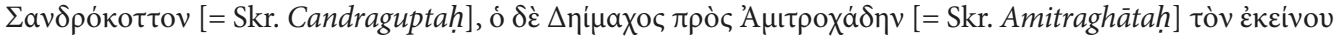
víòv katà $\pi \rho \varepsilon \sigma \beta \varepsilon i a v$. See Christol 2015, 836-843.

7 I quote the Greek text from the bilingual edition by Scholfield (1959, III 236), as well as that by Maspero 1998, II 872. I have also consulted the most recent edition: García Valdés, Llera Fueyo, RodríguezNoriega Guillén 2009, 370-371.

8 Scholfield 1959, III 237. 
In the above passage, Aelian lists some Indian animals participating in the fighting

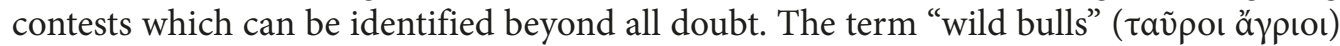

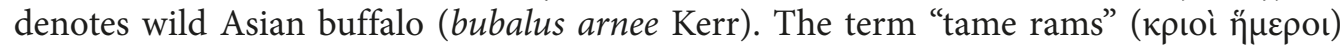
clearly refers to male sheep (Ovis aries L.). The word $\dot{\varepsilon} \lambda \dot{\varepsilon} \varphi$ av $\tau \varepsilon \varsigma$ obviously implies Asian elephants (Elephas indicus L.). The species of the other animals mentioned by Aelian are unknown or highly debatable. ${ }^{9}$ I have augmented Scholfield's translation with some suggestions as to what the missing species may have been, expanding on my hypotheses later

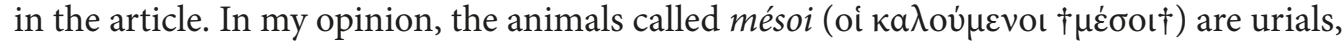
i. e., wild males of the steppe sheep (Ovis aries orientalis Blyth, 1841), while the one-

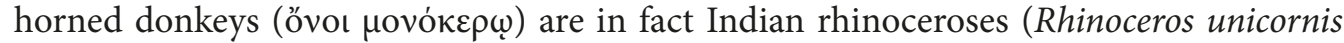
L.), a species that the Greeks and the Romans did not know very well. Aelian discusses the animals called hýainai (†úaıaı $\dagger$ ) at somewhat greater length, describing their appearance and behavior; this makes it possible to identify the actual species (the Indian gazelle, $\mathrm{Ga}$ zella bennettii Sykes, 1831) as well as to restore the original form of the zoonym.

\section{Domesticated rams and wild rams, so-called $\mu \varepsilon \dot{\sigma o t}$}

In the passage under examination, Aelian mentions "domesticated rams and the so-

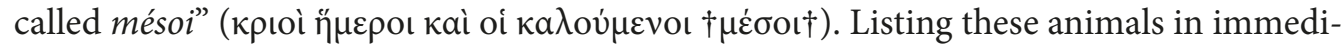
ate succession is not without significance, given that, in my opinion, the spelling $\mu \varepsilon \dot{\varepsilon} \sigma o$ is a phonetic rendering of messa- m. 'ram, sheep', attested in Prakrit in the nominative singular form mé̀so. This word (which is of Indo-European origin) is attested very early, appearing in the Rigveda (Ved. mēșá- m. 'ram') ${ }^{10}$ and continues into Modern Indic languages, e.g., Hi. mes m. 'ram. ${ }^{11}$ The Greek form $\mu \varepsilon \dot{\varepsilon} \sigma o$ is based on the Prakrit (and Pali) nominative singular méso and displays the stress shift posited both for Classical Sanskrit $\left(5^{\text {th }}-10^{\text {th }} \mathrm{c}\right.$. $\mathrm{AD})^{12}$ and the Prakrits. That is to say, there is full segmental and supra-segmental consistency between the Greek rendering and its Middle Indic original.

Most significantly, the zoonym $\mu \varepsilon \dot{\sigma} \sigma o$ cannot denote domesticated rams since these

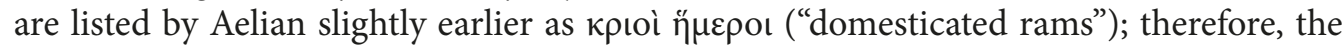
reference must be to the wild species described as "the rams called mésoi". A crucial question thus arises as to what kind of an animal this could be, and the lexical material from Indo-Aryan helps resolve this issue. The Dardic languages spoken in the north-western extremities of the Indian subcontinent display not only the basic meaning of "ram, domestic sheep," but also the specialized meaning referring to the wild variety ("urial, male

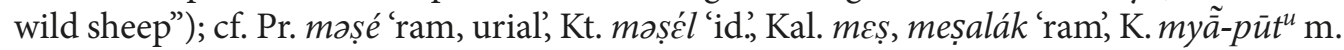
'the young of sheep or goat. ${ }^{13}$ Thus, it stands to reason to assume that the zoonym $\mu \varepsilon \dot{\varepsilon} \sigma \mathrm{s}$

9 A quick glance at the translations available illustrates the point. Scholfield (1959, II 237) translates literally: "and what are called mesoi and one-horned asses and hyainai", explaining in a footnote that "Mesoi and hyainai have not been identified, and edd. [= editors] regard the words as corrupt". Francesco Maspero 1998, II 873, in his Italian translation, uses suspension points inside square brackets, "[...] gli asini unicorni e [...]", which makes reading extremely difficult. A remark "testo corrotto" is to be found in a footnote.

10 Mylius 1980, 279 ('Widder'); Kochergina 1987, 521 ('бара́н’); Pontillo 1996, 376 ('montone; pecora; segno zodiacale dell'Ariete'); Monier-Williams 1999, 833 ('ram').

11 See Turner 1966, 597.

12 According to Pobożniak 1986, 59, "the most characteristic feature of Classical Sanskrit is the disappearance of free word stress, which was inherited from Proto-Indo-European, and the fixing of stress on the penultimate or antepenultimate sound".

${ }^{13}$ See Turner 1966, 597. 
$(\leftarrow \mathrm{Pk}$. méso nom. sg. 'ram, sheep') denotes the male wild sheep. (Ovis aries orientalis Blyth, 1841). The male urial is of light-brown color, has a long beard, usually white, and massive horns bending outward, which can reach up to one metre in length. Adults may weigh as much as $90 \mathrm{~kg}$. This species is still extant in Kashmir and northern Pakistan. ${ }^{14}$

At this point, it is worth noting that the Old Indic appellative meșá- m. 'ram' has Indo-European origins and derives from the proto-form ${ }^{\star}$ moisós or ${ }^{\star}$ maisós $\mathrm{m}$. 'ram, sheep. ${ }^{15}$ Its closest counterparts occur in Iranian languages, e.g., Av. maēša- m. 'ram', maēš̄i- f. 'ewe'; Parth. myš m. 'ram'; NPers. mēš m. 'id.; Kurd. mē, mī f. 'sheep; Psht. maž m. 'ram, mež f. 'sheep; Khwar. 'mh f. 'sheep (< ${ }^{*}$ maiš̄i-); Yaghn. meš m. 'ram, sheep; Shu. maž f. 'sheep.' ${ }^{16}$ The Indo-European word is also attested in Phrygian, cf. Hesychius's gloss $\mu \tilde{\alpha} \cdot \pi \rho o ́ \beta a \tau \alpha$.

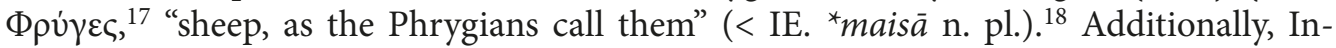
do-Iranian borrowings are attested in Finno-Ugric languages, cf. Zr. mež 'ram', Cher. miž, mež 'wool, hair.' ${ }^{19}$ Possibly, Gk. Att. $\mu$ ẽov n. 'a lamb or a sheep sacrificed during Apatouria' also belongs to the Indo-European root denoting sheep. ${ }^{20}$ North Indo-European languages have retained the derivative form ${ }^{*}$ móisos (or ${ }^{*}$ máisos) $\mathrm{m}$. 'ram's or sheep's skin', hence 'leather sack, bellows' arising from the accentual opposition, cf. Lith. maĩšas m. 'leather sack, big sack', Latv. màiss m. 'sack', OPrus. moasis m. 'bellows'; ${ }^{21}$ OCS. мnoxr m. 'leather sack, bellows, Russ. мex m. 'animal fur; bellows', Cz. mech m. 'bellows; instrument case', archaic 'sack; fishing or hunting net', Pol. miech m. 'sack, bag, purse; bellows'; ${ }^{22} \mathrm{ON}$. meiss m. 'wicker basket', OHG. meisa f. 'wooden sling for moving items on one's back' < PG. * máisaz m. 'carrying bag. ${ }^{23}$

The adaptation of the Middle Indic zoonym ${ }^{*} m \bar{e} s a-\mathrm{m}$. 'ram, male domestic sheep; urial, male wild sheep' (cf. Pk. mēsa- m. 'ram, sheep', nom. sg. mếso) to the phonetic and inflectional system of Greek by means of the spelling ${ }^{\star} \mu \varepsilon \dot{\sigma} \sigma o \varsigma$ (pl. $\mu \varepsilon \dot{\varepsilon} \sigma o \mathrm{o}$ ) is fully expectable. In other words, the reading $\mu \varepsilon \dot{\sigma o l}$, preserved in the De natura animalium codices, is not corrupt and requires no editorial intervention (such as marking the word with a crux philologorum or reconstructing it from partial data). Nor is there a need to question the correctness of hapax legomenon $\mu \varepsilon \dot{\varepsilon} \sigma o$ or refer the reader to the Hesychian gloss (HAL

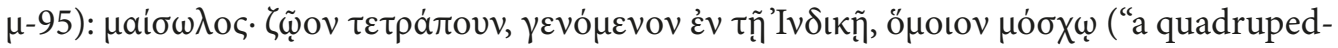
al animal living in the territory of India which resembles a calf"). ${ }^{24}$ The word $\mu \alpha i \sigma \omega \lambda o \varsigma$, recorded once in Hesychius' lexicon, has actually nothing to do with the zoonym $\mu \dot{\varepsilon} \sigma o \mathrm{o}$ being a derivative (a diminutive form) of another Old Indic appellative, namely mahisá-

14 See ill. at https://commons.wikimedia.org/wiki/File:Ovis_ammon_vignei_arkal_Pretoria_3.jpg.

15 Pokorny 1959, 747; Mayrhofer 1963, 689; Mayrhofer 1996, 380.

16 Bartholomae 1904, 1109; Morgenstierne 1927, 49; Morgenstierne 1974, 44; Bailey 1979, 332; Tsabolov 2001, 676; Morgenstierne 2003, 48.

17 Latte 1966, 620.

18 Witczak 2003, 148.

19 Bur. mēș 'skin-bag' is also an old Indo-Iranian loan; see Mayrhofer 1963, 689.

20 See Kroonen 2013, 349. A different etymology is posited by Beekes 2010, 921.

${ }^{21}$ Fraenkel 1962, 397; Smoczyński 2007, 368.

22 Brückner 1927, 331; Bańkowski 2000, 174; Boryś 2005, 322-323; Mańczak 2017, 112.

23 Kroonen 2013, 348-349.

24 As it was first attempted by Conrad Gesner, who procured the editio princeps of NA: "Mغ́øo animalia cornuta quae sint ignorare me fateor. Mai $\sigma \omega \lambda$ oৎ Hesychio in India sunt quadrupedes vitulis similes" (Gesner 1556, 318; cf. Latte 1966, 622). 
m. 'buffalo', which is based on the adjective mahisá- 'great, powerful',25 cf. Ved. máhi- adj. 'id.' = Gk. $\mu \dot{\varepsilon} \gamma$ as adj. 'great, big, large. ${ }^{26}$

\section{The Indian animals called v̌aıvaı (?)}

Dictionaries of Ancient Greek list three zoological meanings of the word vैaıva: (1) 'striped hyena, Hyaena hyaena L.; (2) 'a species of the antelope'; (3) 'an unidentified sea fish. ${ }^{27}$ The second meaning is only attested in the very passage of Aelian under discussion $(N A 15,15) .{ }^{28}$ However, the present-day editors deem the ms. reading corrupt, and print it sub cruce. ${ }^{29}$ Fortunately, in addition to providing the Indian animal's name, Aelian also

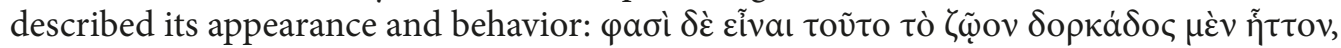

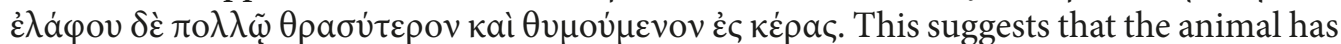
horns or antlers, is smaller than $\delta$ o кác, and exceptionally combative, more so than deer during the mating period.

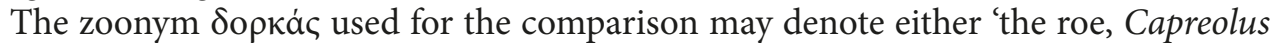
capreolus L., if the description concerns an animal living in Europe, or 'the Dorcas gazelle, Gazella dorcas L., or alternatively 'the Thomson's gazelle Eudorcas thomsonii Günther', if the description refers to North Africa or Ethiopia. ${ }^{30}$ It cannot be stated with absolute certainty which of these Aelian (or Megasthenes) decided to compare them to the Indian animal involved in the fighting contests at King Chandragupta's court. At this point, it is

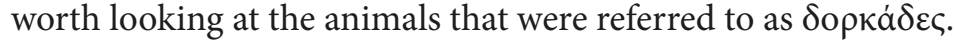

The roe is a middle-sized, slender animal with long legs, reddish-brown coat (in summer) with a white or yellowish spot on the buttocks. It is between 95-135 cm long, 70-90 cm tall (measured to the withers), and it weighs between 18 and $30 \mathrm{~kg} .{ }^{31}$ The Dorcas gazelle is similar to the roe, but it is slightly smaller (between 90 and $110 \mathrm{~cm}$ long, 55-65 cm tall when measured to the withers, weighing between 15 and $20 \mathrm{~kg}$ ). The Thomson's gazelle has longer and more twisted legs, and its colour is similar to that of the Dorcas gazelle, but it is closer in size to the roe (between 80 and $110 \mathrm{~cm}$ long, $60-90 \mathrm{~cm}$ tall when measured to the withers, weighing between 30 and $35 \mathrm{~kg}$ ). Thus, it appears that the roe, being larger than the Dorcas gazelle and Thomson's gazelle, is the optimal reference point.

The term ع́ $\lambda \alpha \varphi$ ○ ' 'red deer, Cervus elaphus L.' clearly suggests that either Aelian himself or Megasthenes compared Indian animals to European ones (the red deer does not live in Africa).$^{32}$ There is no question that the Indian "horned animal" described by Aelian is a middle-sized animal, yet it is smaller than the roe.

${ }^{25}$ In the critical apparatus, Kurt Latte commented: “Ind. mahișáh 'bubalus' Charpentier KZ 45, 94, 4".

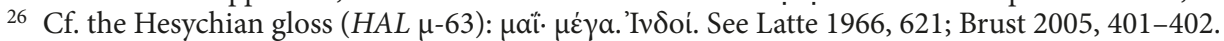

27 Beside LSJ e. g. Abramowiczówna 1965, 381; Jurewicz 2001, 421. It should be noted that Montanari 2018 , 75, does not include meaning (2), considering the locus dolens in NA unexplainable.

${ }^{28}$ Kitchell 2014, 93.

29 Scholfield 1959, III 236; Maspero 1998, II 872. Other publishers of Aelian's work pointed to the corruption of the text in the critical apparatus: see Hercher 1864, LIII, ad p. 379 ("vox corrupta"); García Valdés, Llera Fueyo, Rodríguez-Noriega Guillén 2009, 370 (“vaaıaı] susp.: voc. corrupt.").

${ }^{30}$ See LSJ s. v.; Kitchell 2014, 59-60.

31 L. J. Dobroluka 1998, 152.

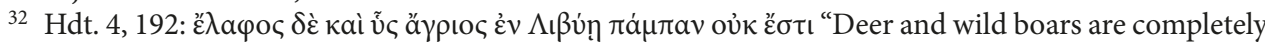
absent from Libya (i.e., Africa)". The Roman encyclopedist Pliny the Elder expresses a similar opinion on two occasions, see Pl. HN 8, 51, 120: cervos Africa propemodum sola non gignit "Africa is the only land where 
I share the view of all the editors that the reading v́aıva is corrupt. ${ }^{33}$ However, I believe that it is the copyists who are at fault, having associated the unfamiliar name of an Indian animal with the Greek zoonym úaıva f. 'striped hyena'. This would be perfectly tenable under the assumption that Aelian had adduced the foreign word, taken from the language of the local community, as he did (probably after Megasthenes) in the case of the Middle Indic name of the wild ram. Since the horned animal in question did not live in Europe, Aelian, following Megasthenes, provided the reader with a brief but precise description of its characteristics. Based on the above hypothesis, I am inclined to look in the Indo-Aryan lexicon for a zoonym whose phonetic form resembles the reading túaıva $\dagger$ [hýainai], transmitted in all codices of De natura animalium. ${ }^{34}$

The Rigveda, the oldest literary source for the Indo-Aryan languages, lists five names of species that refer to horned animals similar to the deer, the antelope, or the gazelle: rśya-, prșatá-, mrgá-, rúru-, hariná. ${ }^{35}$ Of these, the one most closely resembling the phonetic transcription [hýaina] is the zoonym hariná- m. 'gazelle', harinī' f. 'female gazelle, ${ }^{36}$ which is well attested in Middle Indic (cf. Pa. harina- m., harin̄i-f. 'deer', Pk. harina- m., harin̄i- $\mathrm{f}$. 'deer') and Modern Indic languages ${ }^{37}$ (cf. La. haran m., harṇi f. 'Indian gazelle/ravine deer; As. harinā; B. harin; Or. harini, haran̄̄ f.; P. harn, harnā m. 'deer'; Hi. harin, haran, hiran m., harinā, harnā, hirnā m. 'deer'; Guj. haraṇ n. 'deer'; Ma. haraṇ m./f./n., harṇ̄ f. 'id.'). ${ }^{38}$ The Indo-Aryan lexical material clearly shows that the name hariná- denotes 'the Indian gazelle, Gazella bennettii Sykes, ${ }^{39}$ referred to as the ravine deer in English. ${ }^{40}$

The Indian gazelle, also called the chinkara, has a light-brown coat, except for its belly, which is white-grey. It is smaller than the roe $(65 \mathrm{~cm}$ measured to the withers, $23 \mathrm{~kg}){ }^{41}$ During the mating period, the male Indian gazelle is hostile toward its competitors. ${ }^{42}$ It is very likely that the corrupted ṽaıva denotes male Indian gazelles. Aelian's comparison of the In-

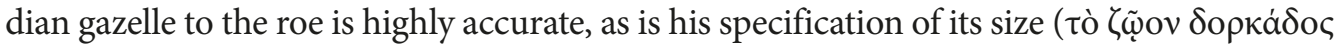
$\mu \grave{\varepsilon} v \tilde{\eta} \tau \tau o v)$. Moreover, the postulated phonetic transcription of the extant reading ũaıvaı [hýainai] closely resembles the Middle Indic name of this animal (Pa. harina-, nom. sg. hárino, nom. pl. hárināa). Therefore, it is feasible to restore the text despite the corrupt data.

no deer are born"; Pl. HN 8, 83, 228: in Africa autem nec apros nec cervos nec capreas nec ursos "In Africa, there are no boars, nor deer, nor roes, nor bears".

33 Already Conrad Gesner in the editio princeps (1556) used a crux philologorum before the word †ưaıval, adding on the margin, "†vocabulum videtur corruptum”; see Gesner 1556, 319.

${ }^{34}$ It is worth remembering that in Megasthenes's times $\left(4^{\text {th }}-3^{\text {rd }} c . B C\right)$ graphic representation of the rough breathing was not yet present.

35 Monier-Williams 1999, 1291.

36 Mayrhofer 1964, 581 ('Gazelle'); Mylius 1980, 573 ('Gazelle, Antilope'); Kochergina 1987, 770 ('газель'); Pontillo 1996, 376 ('cervo, antilope'); Monier-Williams 1999, 1291 ('a deer, antelope, fawn, stag'); Mayrhofer 1996, 805 ('gelbliches Tier, Gazelle').

37 It should be emphasized that the English word deer denotes not just a red deer, but also other Cervidae or Bovidae. Particular species are identified through qualifying adjectives: E. fallow deer (Dama dama L.), raven deer (Gazella bennettii Sykes), red deer (Cervus elaphus L.), reindeer (Rangifer tarandus L.), roe deer (Capreolus capreolus L.), spotted deer (Axis axis Erxleben). It is worth noting that E. deer corresponds to G. Tier n. 'animal' and goes back to PG. *deuzan n. 'wild animal', see Kroonen 2013, 94-95.

38 Turner 1966, 809.

39 The Vedic term hariná- is etymologically related to the Old Indic adjective harí-adj. 'reddish-brown, brown, fallow, pale yellow, greenish", cf. Lat. helvus adj. 'fallow; yellowish' (< IE. * $\hat{g} h e l-)$. See Mayrhofer 1964, 581; Mayrhofer 1996, 805; de Vaan 2008, 282. Therefore, the zoonym refers to the colour of the chinkara.

40 Yule, Burnell 1996, 758.

41 Kowalski 1991, 87.

42 See ill. at https://commons.wikimedia.org/wiki/File:Chinkara_at_Ranthambore.jpg. 
The reading preserved in the codices stands out for lack of the liquid consonant $[\mathrm{r}]$ in the word-medial position. The easiest assumption to make is that the original Greek reading had the letter $\rho$. Adding one letter to the spelling makes it possible to restore the word: The posited form v́ápıvaı [hyárinai] rather successfully renders the Pali and Prakrit nominative plural hárina $\bar{a}$ (Indian gazelles). The suggested emendation meets the basic criterion of restauration from corrupted data since it requires the smallest possible alteration of the extant text. The Greek ending - $\alpha$ is to be explained by the adaptation of a foreign form (Pa., Pk. hárināa ) to the Greek inflectional system. To be sure, however, it cannot be ruled out that the original text (by Megasthenes) featured the form ăpıvaı [hárinai]. In any case, the eventual form of úaıva very likely results from the actions of a copyist who replaced an unfamiliar word with one that had a similar pronunciation, having deliberately drawn on a Greek zoonym.

\section{Conclusions}

Thus, a critical analysis of Ael. NA 15, 15, which I believe is based on the corresponding passage of Megasthenes's Indica, accompanied by a detailed study of Greek and Indian zoonyms permits the following conclusions.

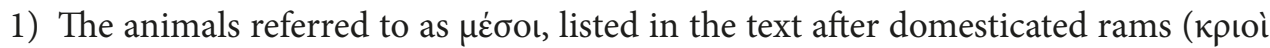

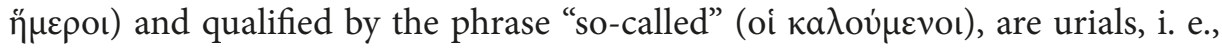
males of the wild steppe sheep. The name $\mu \dot{\varepsilon} \sigma o \mathrm{l}$, which in the zoological sense is a typical hapax legomenon, is an example of a Greek phonetic and morphological rendering of the Middle Indic word mēsa- m. 'ram, urial', cf. Pk. mēsa- m. 'ram, sheep' (nom. sg. mếso), Hi. mes m. 'ram', Pr. mașé 'ram, urial.'

2) The description of the horned animals labelled with the corrupt term v́aıvaı leaves no doubt that these are not "striped hyenas" but rather Indian gazelles (Gazella bennettii Sykes). I have proposed a small alteration to the spelling, adding one letter

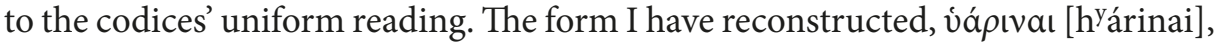
seems a near-optimal adaptation of the Pali or Prakrit word hárināa (nom. pl.). The correct form of vápıval was corrupted as a result of its etymologically unfounded association with the purely Greek form ũaıval f. pl. 'striped hyenas'.

\section{Abbreviations}

As. - Assamese; Att. - Attic Greek; Av. - Avestan; B. - Bengali; Bur. - Burushaski; Cher. Che-remis; Cz. - Czech; E. — English; G. - German; Gk. — Greek; Guj. — Gujarati; Hi. — Hindi; IE. Indo-European; K. — Kashmiri; Kal. — Kalasha; Khwar. — Khwarezmian; Kt. — Kati; Kurd. — Kurdish; La. Lahnda;Lat. — Latin;Latv. — Latvian; Lith. — Lithuanian;Ma. — Marathi;NPers. — New Persian;OHG. _ Old High German; OCS. — Old Church Slavic; ON. — Old Norse; OPrus. — Old Prussian; Or. — Oriya; P. — Panjabi; Pa. - Pali; Parth. — Parthian; PG. — Proto-Germanic; Pk. — Prakrit; Pol. — Polish; Pr. — Prasun; Psht. Pashto; Russ. - Russian; Shu. - Shughni; Skr. - Sanskrit; Ved. - Vedic; Yaghn. - Yaghnobi; Zr. — Ziryene.

\section{References}

Abramowiczówna Z. Słownik grecko-polski, vol. IV. Warszawa, PWN, 1965.

Bailey H.W. Dictionary of Khotan Saka. Cambridge - London - New York - Melbourne, Cambridge University Press, 1979. 
Bańkowski A. Etymologiczny słownik języka polskiego, vol. II. Warszawa, Wydawnictwo Naukowe PWN, 2000.

Bartholomae Ch. Altiranisches Wörterbuch. Strassburg, Verlag von Karl J. Trübner, 1904.

Beekes R. Etymological Dictionary of Greek. Leiden - Boston, Brill, 2010.

Boryś W. Stownik etymologiczny języka polskiego. Kraków, Wydawnictwo Literackie, 2005.

Brust M. Die indischen und iranischen Lehnwörter im Griechischen. Innsbruck, Institut für Sprachen und Literaturen der Universität Innsbruck, 2005.

Brückner A. Słownik etymologiczny języka polskiego. Kraków, Krakowska Spółka Wydawnicza, 1927.

Christol A. Greek and Indian Languages, in: A.-F. Christidis (ed.), A History of Ancient Greek from the Beginnings to Late Antiquity, vol. I. Cambridge, Cambridge University Press, 2015, 836-843.

de Vaan M. Etymological Dictionary of Latin and the other Italic Languages. Leiden - Boston, Brill, 2008.

Dobroluka L. J. Mammals. Prague, Blitz Editions, 1998.

Fraenkel E. Litauisches etymologisches Wörterbuch, vol. I. Heidelberg, Carl Winter, 1962.

García Valdés M., Llera Fueyo L. A., Rodríguez-Noriega Guillén L. Claudius Aelianus, De natura animalium. Berolini - Novi Eboraci, De Gruyter, 2009.

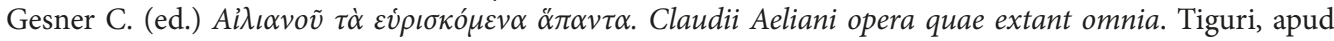
Gesneros fratres, 1556.

Hercher R. (ed.) Claudii Aeliani De natura animalium libri XVII. Lipsiae, B. G. Teubner, 1864.

Jurewicz O. Słownik grecko-polski, vol. II. Warszawa, Wydawnictwo Szkolne PWN, 2001.

Kitchell K. F. Animals in the Ancient World from A to Z. London - New York, Routledge, 2014.

Kowalski K. (ed.). Mały słownik zoologiczny. Ssaki. Warszawa, Wiedza Powszechna, 1991.

Kochergina V. A. Sanskritsko-russkii slovar'. Moskva, Izdatel'stwo "Russkii Iazyk", 1987. [Kochergina V. A. Sanskrit-Russian Dictionary. Moscow, Publishing House "Russian Language", 1987]. (In Russian)

Kroonen G. Etymological Dictionary of Proto-Germanic. Leiden — Boston, Brill, 2013.

Latte K. (ed). Hesychii Alexandrini Lexicon, vol. II. Hauniae, Ejnar Munksgaard Editore, 1966.

Mańczak W. Polski słownik etymologiczny. Kraków, Polska Akademia Umiejętności, 2017.

Maspero F. Claudio Eliano, La natura degli animali, vol. I-II. Milano, RSC Libri, 1998.

Mayrhofer M. Kurzgefaßtes etymologisches Wörterbuch des Altindischen, vol. II-III. Heidelberg, Carl Winter, 1963-1964.

Mayrhofer M. Etymologisches Wörterbuch des Altindoarischen, vol. II. Heidelberg, Carl Winter, 1996.

Monier-Williams M. A Sanskrit-English Dictionary. Delhi, Motilal Banarsidass Publishers, 1999.

Montanari F. The Brill Dictionary of Ancient Greek. Leiden - Boston, Brill, 2018.

Morgenstierne G. An Etymological Vocabulary of Pashto. Oslo, I Kommisjon Hos Jacob Dybwad, 1927.

Morgenstierne G. Etymological Vocabulary of the Shughni Group. Wiesbaden, Dr. Ludwig Reichert Verlag, 1974.

Morgenstierne G. A New Etymological Vocabulary of Pashto. Wiesbaden, Dr. Ludwig Reichert Verlag, 2003.

Mylius K. Wörterbuch Sanskrit-Deutsch. Leipzig, VEB Verlag Enzyklopädie, 1980.

Pobożniak T. Języki indyjskie [Indo-Aryan Languages], in: L. Bednarczuk (ed.), Języki indoeuropejskie [Indo-European Languages], vol. I. Warszawa, PWN, 1986, s. 245-273.

Pokorny J. Indogermanisches etymologisches Wörterbuch. Bern-München, Francke Verlag, 1959.

Pontillo T. Dizionario sanscrito. Milano, Garzanti Editore, 1996.

Scholfield A.F. (ed.) Aelian, On the Characteristics of Animals, vol. II-III. London, William HeinemanCambridge (MA), Harvard University Press, 1959.

Smoczyński W. Słownik etymologiczny języka litewskiego. Wilno, Uniwersytet Wileński, 2007.

Stein O. Megasthenes, in: RE 1931 XV (29), 230-326.

Tsabolov R. L. Etimologicheskii slovar' kurdskogo iazyka, vol. I. Moskva, Izdatel'skaia Firma "Vostochnaia Literatura" RAN, 2001. [Tsabolov R. L. Etymological Dictionary of the Kurdish language, vol. I. Moscow, Publishing House "Eastern Literature" of the Russian Academy of Sciences, 2001]. (In Russian)

Turner R.L. A Comparative Dictionary of the Indo-Aryan Languages. London - New York - Toronto, Oxford University Press, 1966.

Witczak K. T. New Evidence for the Indo-European Terminology for 'sheep'. Lingua Posnaniensis 2003, 45, 143-150.

Yule H., Burnell A. C. Hobson-Jobson. The Anglo-Indian Dictionary. London, Wordsworth Editions, 1996.

Received: December 29, 2019

Accepted: February 8, 2021 